\title{
Tindakan Main Hakim Sendiri (Eigenrichting) Terhadap Pelaku Khalwat Sebagai Dalih Kebiasaan Masyarakat Di Aceh
}

\author{
Syarifah Rahmatillah*1, Amrullah Bustamam ${ }^{2}$ \\ 1,2 Universitas Islam Negeri Ar-Raniry, Indonesia \\ e-mail: ${ }^{* 1}$ syarifah.rahmatillah@ar-raniry.ac.id, ${ }^{2}$ Aamrullah@ar-raniry.ac.id
}

\begin{abstract}
This study discusses the act of vigilantism (eigenrichting) carried out by a group of people in the community against men and women who are suspected of committing acts of khalwat in Aceh, such as persecution, beating, confinement, or other acts of hurt or distress. This research is a descriptive qualitative research, which studies in depth and holistically with the type of field research and uses a sociological juridical approach. Data obtained through observation and interviews conducted independently and controlled. While the data were analyzed using four components of interactive analysis, namely data collection, data reduction, data presentation, and drawing conclusions/verification. The results of the study show that, firstly, vigilantism is still practiced by the community against the perpetrators of khalwat, such as bathing with sewage water, hitting, parading around the village of the perpetrators of seclusion. Second, the Government through the Department of Islamic Law and Wilayatul Hisbah in Langsa City, Banda Aceh and Aceh Besar District has made various efforts to minimize vigilante treatment by socializing the provisions of the Jinayah Qanun related to procedures for resolving cases of seclusion.
\end{abstract}

Keywords: Playing Judges Alone, Seclusion, Aceh, Islamic Shari'a

\begin{abstract}
Abstrak
Studi ini membahas tentang tindakan main hakim sendiri (eigenrichting) yang di lakukan oleh sekelompok orang dalam komunitas masyarakat kepada lelaki dan perempuan yang di duga melakukan perbuatan khalwat di Aceh, seperti penganiayaan, pemukulan, penyekapan, atau tindakan menyakiti atau mempersusah lainnya. Penelitian ini merupakan penelitian deskriptif kualitatif, yang mempelajari secara mendalam dan holistis dengan jenis penelitian lapangan serta menggunakan pendekatan yuridis sosiologis. Data diperoleh melalui observasi serta wawancara yang dilakukan secara mandiri dan terkontrol. Sedangkan data dianalisis dengan menggunakan empat komponen analisis interaktif, yaitu pengumpulan data, reduksi data, penyajian data, dan penarikan
\end{abstract}


kesimpulan/verifikasi. Hasil penelitian menunjukkan bahwa, pertama, main hakim sendiri masih dilakukan oleh masyarakat terhadap pelaku khalwat, seperti memandikan dengan air comberan, memukul, mengarak keliling kampung pelaku khalwat. Kedua, Pemerintah melalui Dinas Syariat Islam dan Wilayatul Hisbah di kota Langsa, Banda Aceh maupun di Kabupaten Aceh Besar telah melakukan berbagai upaya untuk meminimalisirnya perlakuan main hakim sendiri dengan cara melakukan sosialisasi ketentuan Qanun Acara Jinayah terkait tata cara penyelesaian kasus khalwat.

Kata Kunci: Main Hakim Sendiri, Khalwat, Aceh, Syariat Islam

\section{PENDAHULUAN}

Dewasa ini masih banyak terjadi tindak kekerasan dalam masyarakat. Tindak kekerasan tersebut dilakukan oleh individu maupun secara bersamasama atau oleh massa. Tindak kekerasan oleh massa dalam hal ini adalah main hakim sendiri terhadap pelaku kejahatan maupun pelaku pelanggaran. Tindakan main hakim sendiri merupakan suatu tindakan yang dilakukan oleh seseorang atau sekelompok orang terhadap orang lain dalam bentuk menghakiminya karena suatu perbuatan yang dilakukan yang dianggap salah oleh masyarakat setempat (Abbas et al., 2016).

Terminologi hukum pidana tidak memuat istilah main hakim sendiri. Untuk dapat dikatakan suatu perbuatan termasuk kedalam suatu tindak pidana, maka perbuatan tersebut harus secara tegas diatur dalam peraturan perundangundangan pidana yang berlaku di Indonesia (Muhibbuthabry, 2014). Tindakan main hakim sendiri (eigenrichting), bukanlah suatu jenis tindak pidana yang diatur secara tegas sebagai suatu pasal perbuatan pidana dalam KUHP atau undang-undang pidana diluar KUHP (Abbas et al., 2016). Dampak dari tindakan main hakim sendiri dapat digolongkan kedalam beberapa jenis tindak pidana, seperti tindakan pengancaman, penganiayaan, hingga penculikan yang diatur dalam Buku II tentang Kejahatan dalam KUHP.

Di Indonesia tindakan main hakim sendiri telah menjadi definisi yang diterima secara umum oleh masyarakat, yakni perbuatan sekelompok orang (biasanya warga) yang kebetulan memergoki terjadinya suatu perbuatan tindak pidana, kemudian sekelompok warga tersebut bertindak dengan mengejar, menangkap, kemudian menganiayanya, bisa dengan memukul, menendang, menampar, hingga membunuhnya (Murziqin, et.al., 2016; Hamzah, 2010; Rukmini, 2003). Beberapa tindakan tersebut terkadang juga di ikuti dengan 
mengambil foto atau merekam videokan tindakan main hakim tersebut untuk kemudian di Viralkan di media sosial.

Merujuk pada ketentuan hukum pidana dalam KUHP, maka ada beberapa pasal yang bisa digunakan untuk menjerat pelaku main hakim sendiri. Seperti pengancaman pasal 368, penganiayaan 351, pengeroyokan 170, atau pembunuhan pasal 338.

Namun, yang menarik, ada beberapa jenis tindakanmain hakim sendiri yang dilakukan oleh sebagian warga masyarakat terhadap pelaku mesum, zina, khalwat yaitu memandikan pelaku dengan air comberan, memandikan dengan air bak wudhu di tengah malam, di arak keliling desa dan lain sebagainya. Perlakuan main hakim sendiri ini dikatakan dilakukan dengan dalih bahwa ini adalah suatu kebiasaan masyarakat setempat sejak dulu sampai sekarang.

Contoh kasus yang terjadi terhadap Kepala Bappeda Kota Langsa dengan insial SF(52), yang sempat di hakimioleh sebagian masyarakat setempat karena dianggap membawa perempuan yang bukan muhrimnya ke rumah salah satu warga. Akibatnya sekitar pukul 16.30 WIB, hari Sabtu 28Juli 2018, Kepala Bappeda Langsa yang terciduk saat penggerebekan oleh warga dimandikan dengan air comberan. Walaupun kemudian informasi yang berkembang selanjutnya dalam pemberitaan di media media on line dan cetak, menyatakan bahwa sebenarnya pasangan yang dimandikan itu adalah pasangan yang sah dan telah menikah secara siri (Jawapos : 2018).

Ombudsman RI Perwakilan Aceh menilai tindakan main hakim sendiri yang dialami Kepala Bappeda Kota Langsa TSF, dengan dimandikan air comberan oleh warga karena dianggap telah melakukan perbuatan mesum, melanggar hukum adat dan tidak sesuai dengan qanun Aceh nomor 9 tahun 2008 Tentang Pembinaan Kehidupan Adat dan Istiadat. Qanun tersebut memuat 18 macam perkara yang bisa diselesaikan di desa (gampong). Diantaranya, perselisihan dalam rumah tangga, sengketa antara keluarga yang berkaitan dengan faraidh, perselisihan antar warga, khalwat mesum, dan pelecehan, fitnah, hasut, dan pencemaran nama baik (Kumparan, 2018).

Kasus selanjutnya adalah, main hakim sendiri terhadap seorang pemuda bernama Dani Syahputra umur 24 tahun yang mengakibatkan kematian. Dani adalah warga Desa Bantayan, Kecamatan Nurussalam, Aceh Timur. Kejadian main hakim sendiri ini terjadi pada Kamis 19 juli 2017 (Kompas : 2018). Masih banyak kasus perskusi lainnya yang dilakukan warga terhadap pelaku mesum, 
zina, khalwat di Aceh walaupun qanun jinayah dan qanun pidana adat sudah di berlakukan. Penelitian ini bertujuan untuk mengetahui apa penyebab masyarakat tidak mengindahkan aturan hukum yang berlaku dalam proses upaya tangkap tangan saat terjadi kasus khalwat di Aceh.

\section{LANDASAN TEORI}

\section{Persekusi Dalam Perspektif Hukum Pidana}

Persekusi adalah tindakan main hakim sendiri (eigenrichting). Negara Indonesia adalah negara hukum, demikian bunyi Pasal 1 Ayat (3) UUD 1945 setelah diamandemen ketiga disahkan 10 November 2001. Penegasan dalam konstitusi ini bermakna, bahwa segala aspek kehidupan dalam kemasyarakatan, kenegaraan dan pemerintahan harus senantiasa berdasarkan atas hukum. Untuk mewujudkan negara hukum salah satunya diperlukan perangkat hukum yang digunakan untuk mengatur keseimbangan dan keadilan di segala bidang kehidupan dan penghidupan rakyat melalui peraturan perundang-undangan (Muhibbuthabry, 2014; Sasangka, 2003; Mertokusumo, 1999).

Menurut John Locke, negara terbentuk berdasarkan pactum unionis, yaitu perjanjian antar individu untuk membentuk Negara (Fauzi, 2003). Dengan demikian, setiap individu telah menyerahkan hak-haknya secara sukarela kepada negara dalam suatu kontrak social (du Contrat Social). Oleh karena itu, negara diberikan kewenangan untuk menegakkan hukum terhadap siapapun sebagaimana telah digariskan dalam undang-undang (ius puniendi).

Tindakan persekusi terhadap remaja adalah tindakan main hakim sendiri. Hal tersebut melanggar hukum yang berlaku di Indonesia, yaitu pasal tentang larangan melakukan kekerasan baik fisik maupun psikis terhadap anak (Pasal 76C) dan melanggar pasal yang melarang tindakan penculikan (Pasal 76F) UU No.35 Tahun 2014 tentang Perubahan Atas UU No.23 Tahun 2002 tentang Perlindungan Anak.

Sedangkan tindakan persekusi apabila dilakukan terhadap orang dewasa maka penerapan pasalnya berbeda sesuai jenis arah tindak perlakuan. Misalkan dikenakan Pasal 328 KUHP (Penculikan). Kedua, Pasal 351 KUHP apabila penganiayaan yang dilakukan berakibat luka berat dan mati atau Pasal 352 KUHP apabila penganiayaannya tidak menyebabkan sakit. Ketiga, dapat dikenakan Pasal 335 (1) ke-1 KUHP (versi pasca putusan MK Nomor 1/PUUXI/2013) karena secara melawan hukum memaksa orang lain supaya melakukan 
sesuatu, dengan memakai kekerasan, atau dengan memakai ancaman kekerasan (hukumonline.com: 2018).

Artinya, persekusi tersebut akan mengarah ke jenis tindak pidana apa yang mereka lakukan, selanjutnya sistem peradilan pidana akan menyelesaikan berdasarkan ketentuan hukum yang berlaku yaitu, KUHP, KUHAP, undangundang tindak pidana khusus dan hukum acaranya.

\section{Penegakan Hukum Melalui Sistem Peradilan Pidana di Indonesia}

Sistem Peradilan Pidana (SPP) atau criminal justice system kini telah menjadi suatu pedoman yang menunjukkan mekanisme kerja dalam penanggulangan kejahatan dengan menggunakan dasar pendekatan sistem (Abbas et al., 2016; Makarao, et al., 2004; Nasution, 1975). Menurut Remington dan Ohlin, criminal justice system diartikan sebagai pemakaian pendekatan sistem terhadap mekanisme administrasi peradilan pidana, dan peradilan pidana sebagai suatu sistem merupakan hasil integrasi antara peraturan undangundang, praktik administrasi dan sikap atau tingkah laku sosial, pengertian sistem itu sendiri mengandung implikasi suatu proses interaksi yang dipersiapkan secara rasional dan dengan cara efesien untuk memberikan hasil tertentu dengan segala keterbatasannya (Anwar, 2009; Abbas et al., 2016).

Menurut Mardjono sebagaimana yang dikutip Romli Atmasasmita bahwa yang dimaksud dengan sistem peradilan pidana adalah sistem pengendalian kejahatan yang terdiri dari lembaga-lembaga kepolisian, kejaksaan, pengadilan, dan pemasyarakatan. Sedangkan menurut Hagan (1987) "criminal justice system" adalah koneksi antara keputusan dari setiap instansi yang terlibat dalam proses peradilan pidana (Atmasasmita, 2010).

Tujuan peradilan pidana adalah untuk memutuskan apakah seseorang bersalah atau tidak, peradilan pidana dilakukan dengan prosedur yang diikat oleh aturan-aturan ketat tentang pembuktian yang mencakup semua batas-batas konstitusional dan berakhir pada proses pemeriksaan dipengadilan (Abbas et al., 2016). Kaitannya dengan tujuan peradilan seperti yang dinyatakan oleh Harry C Bredemeire sebagaimana yang dikutip Yesmil Anwar dan Adang, bahwa tugas pengadilan adalah untuk membuat suatu putusan yang akan mencegah konflik dan gangguan terciptanya (Anwar, 2009).

Sistem peradilan pidana Indonesia merupakan perwujudan tatanan hukum yang harus ditempuh demi terwujudnya keadilan yang dicitakan oleh 
negara demi tercapainya suatu ketertiban, ketentraman, keadilan dan kesejahteraan (Abbas et al., 2016). Lembaga peradilan diharapkan menjadi tempat terakhir di dunia bagi masyarakat mendapatkan keadilan dan menaruh harapan. Sampai sekarang pengadilan masih dipercaya masyarakat sebagai lembaga untuk menyelesaikan sengketa. Bahkan sebagian masyarakat pernah memberikan label sebagai "benteng keadilan".

Secara teori keberadaan pengadilan merupakan suatu lembaga yang berfungsi untuk mengkoordinasi sengketa-sengketa yang terjadi dalam masyarakat, dan merupakan 'rumah pengayom' bagi masyarakat pencari keadilan, yang mempercayai jalur litigasi serta dianggap sebagai 'perusahaan keadilan' yang mampu mengelola sengketa dan mengeluarkan produk keadilan yang bias diterima oleh semua masyarakat (Abbas et al., 2016; Murziqin et al., 2012; Saepullah, 2019). Jadi sebenarnya tugas dan fungsi pengadilan tidak sekadar menyelesaikan sengketa, tetapi lebih dari itu juga menjamin suatu bentuk ketertiban umum dalam masyarakat.

Berdasarkan alasan itulah masyarakat di segala penjuru dunia, termasuk di Indonesia selama beberapa dekade telah memberikan kepercayaan pada pengadilan untuk mengelola sengketa yang dialaminya, dengan harapan akan mendapatkan keadilan sebagaimana secara normatif disebutkan dalam peraturan perundang-undangan. Pada dasarnya penegakan hukum dilakukan oleh alat penegak hukum (law enforcement agency) yang umumnya meliputi kepolisian, kejaksaan, pengadilan, dan yang juga dikenal sebagai jalur hukum (legal corridor) (Muhibbuthabry, 2014). Kita semua mengetahui bahwa jalur hukum terakhir adalah badan peradilan. Ade Saptomo di dalam bukunya menyebutkan bahwa pengadilan dianggap sebagai "benteng terakhir" atau the last fortress dalam tertib hukum (Saptono, 2009).

Sesuai dengan Undang-undang Nomor 8 tahun 1981 tentang Kitab Undang-undang Hukum Acara Pidana (KUHAP) sebagai sebuah instrumen hukum publik yang mendukung pelaksanaan dan penerapan ketentuan hukum pidana materil mempunyai tujuan penting yaitu mencari dan memperoleh kebenaran materil (Umar, et al., 2020). Seperti halnya tujuan pokok hukum adalah menciptakan tatanan masyarakat tertib, menciptakan ketertiban dan keseimbangan. Tercapainya ketertiban di dalam masyarakat adalah dengan harapan kepentingan manusia akan terlindungi (Mertokusumo, 1999; Saepullah, 2019). 


\section{Penegakan Hukum Melalui Qanun Acara Jinayah Aceh}

\section{Aturan Umum Qanun Acara Jinayat}

Konsideran "menimbang" Qanun No.7 Tahun 2013 tentang Hukum Acara Jinayat dijelaskan bahwa Aceh sebagai bagian dari Negara Kesatuan Republik Indonesia diberikan Keistimewaan dan Otonomi khusus, salah satunya kewenangan untuk melaksanakan Syariat Islam, dengan menjunjung tinggi kepastian hukum, keadilan dan kesamaan di depan hukum (Muhibbuthabry, 2014; Umar, et al., 2020; Murziqin, et al., 2012).

Kemudian bahwa aturan yang ada dalam Kitab Undang-Undang Hukum Acara Pidana (KUHAP) belum sepenuhnya dapat memenuhi kebutuhan penegakan hukum jinayat di Aceh oleh karena itu terbentuklah Qanun Aceh tentang Hukum Acara Jinayat. Pada dasarnya Qanun acara ini adalah hukum formilnya qanun jinayat. Oleh karena itu setiap pelanggaran jarimah yang dilanggar oleh masyarakat akan ditindak sesuai aturan Qanun Acara Jinayat (Muhibbuthabry, 2014; Umar, et al., 2020; Murziqin, et al., 2012). Dalam hal ini, asas Lexs Specialis Derogat Lex's Generalis berlaku.

Instintusi yang berwenang menangani pelanggar Qanun Jinayah adalah Kepolisian RI dan Lembaga Wilayatul Hisbah (Muhibbuthabry, 2014). Wilayatul Hisbah yang selanjutnya disingkat WH adalah bagian dari Satuan Polisi Pamong Praja. Kemudian, Polisi Wilayatul Hisbah yang selanjutnya disebut Polisi WH adalah anggota WH yang berfungsi melakukan sosialisasi, pengawasan, penegakan dan pembinaan pelaksanaan Syariat Islam (Muhibbuthabry, 2014; Amrullah, 2014).

Secara umum tugas WH meliputi Penyelidikan, Penyidikan dan Koordinasi dengan pihak POLRI. Tugas Penyelidikan dan penyidikan yang dilaksanakan WH pun sama sepeti Penyelidikan dan Penyidikan yang dilakukan pihak Polri yang diatur di dalam KUHAP. Penyelidikan yang dimaksud disini yaitu serangkaian tindakan penyelidik untuk mencari dan menemukan suatu peristiwa yang diduga sebagai Jarimah guna menentukan dapat atau tidaknya dilakukan penyidikan menurut cara yang diatur dalam Undang-Undang dan/atau Qanun. Penyidikan adalah serangkaian tindakan penyidik dalam hal dan menurut cara yang diatur dalam undang-undang dan/atau Qanun untuk mencari serta mengumpulkan bukti yang dengan bukti itu membuat terang Jarimah yang terjadi guna menemukan Tersangka (Muhibbuthabry, 2014).. 
Dalam konteks penerapan hukum, Qanun Acara Jinayah memiliki asas yang menjadi Roap Mab. Ada beberapa asas yang menaungin Qanun Acara ini tertera dalam Pasal 2, yakni :

1) Legalitas;

2) Keadilan dan keseimbangan;

3) Perlindungan hak asasi manusia;

4) Praduga tidak bersalah (presumption of innocence);

5) Ganti kerugian dan rehabilitasi;

6) Peradilan menyeluruh, sederhana, cepat, dan biaya ringan; g. Peradilan terbuka untuk umum;

7) Kekuasaan hakim yang sah, mandiri dan tetap;

8) Bantuan hukum bagi terdakwa; dan

9) Pembelajaran kepada masyarakat (tadabbur).

Selanjutnya dalam penjelasan Pasal 2 tersebut di jelaskan bahwa yang dimaksud dengan asas "perlindungan hak asasi manusia" adalah suatu asas yang menjamin bahwa proses penegakan hukum akan melindungi hak asasi korban dan pelaku serta pihak lain yang terlibat seperti saksi, secara sungguhsungguh. Hakim berhak bahkan harus memberitahu para pihak, yaitu korban, saksi, terdakwa dan penuntut umum tentang hak-hak mereka selama persidangan dan hak mereka di dalam putusan yang akan dijatuhkan (Muhibbuthabry, 2014; Umar, et al., 2020; Amrullah, 2014).

Dan yang dimaksud dengan asas "praduga tidak bersalah (presumption of innocence) adalah suatu asas yang menghendaki agar setiap orang yang terlibat dalam perkara Jinayat harus dianggap belum bersalah sebelum ada putusan Mahkamah Syar'iyah yang menyatakan kesalahannya itu. Dalam pemeriksaan perkara pada semua tingkatan pemeriksaan semua pihak harus menganggap bagaimanapun juga tersangka/ terdakwa maupun dalam menggunakan istilah sewaktu berdialog terdakwa.

Serta yang dimaksud dengan asas "ganti kerugian dan rehabilitasi" adalah adanya hak orang yang dirampas kebebasannya (ditahan) secara tidak sah atau dinyatakan bebas atau tidak terbukti bersalah oleh hakim untuk mendapat ganti kerugian atas penahanan tersebut serta pemulihan nama baik karena telah ditahan dan diproses atas tuduhan melakukan jarimah. 
Adapun yang dimaksud dengan asas "peradilan menyeluruh, sederhana, cepat, dan biaya ringan" adalah pelaksanaan peradilan yang mencakup semua aspek yang berhubungan, termasuk spek perdatanya. Prosedur yang sesederhana mungkin, sehingga tidak berbelit-belit dan dengan biaya yang seminimal mungkin guna menjaga kestabilan psikologis terdakwa.

Asas menyeluruh menghendaki agar proses pemeriksaan peradilan bukan hanya untuk menjatuhkan uqubat kepada pelaku jarimah, tetapi juga untuk memberikan kompensasi kepada korban jarimah, memberikan rehabilitas kepada pelaku jarimah yang tidak terbukti bersalah.

\section{Hal Penting dalam aturan Upaya Paksa Qanun Jinayat}

Terkait Upaya Paksa dalam penindakan pelanggar Jarimah dalam qanun Jinayat, hal ini di atur dalam BAB V tentang Penangkapan, Penahanan, Penggeledahan Badan, Pemasukan Rumah, Penyitaan Dan Pemeriksaan Surat. Pertama Penangkapan, untuk kepentingan penyelidikan, Penyelidik atas perintah Penyidik berwenang melakukan penangkapan. Untuk kepentingan penyidikan, Penyidik dan Penyidik Pembantu berwenang melakukan penangkapan. Perintah penangkapan dilakukan terhadap setiap orang yang diduga keras melakukan Jarimah berdasarkan bukti permulaan yang cukup. Terhadap Tersangka pelaku Jarimah yang diperiksa dengan acara cepat, tidak dilakukan penangkapan, kecuali dalam hal ia telah dipanggil secara sah 2 (dua) kali berturut-turut tidak memenuhi panggilan itu tanpa alasan yang sah (Muhibbuthabry, 2014; Umar, et al., 2020; Murziqin, et al., 2012).

Kedua Penahanan, Untuk kepentingan Penyidikan, Penuntutan, Penyidangan dan/atau pelaksanaan 'Uqubat terhadap Tersangka, Terdakwa dan terpidana dapat dilakukan Penahanan. Untuk kepentingan Penyidikan, Penyidik berwenang melakukan Penahanan. Untuk kepentingan penyidikan, Penyidik Pembantu atas perintah Penyidik berwenang melakukan Penahanan. Untuk kepentingan Penuntutan, Penuntut Umum berwenang melakukan Penahanan atau Penahanan Lanjutan. Untuk kepentingan pemeriksaan di sidang Mahkamah, Hakim dengan penetapannya berwenang melakukan Penahanan dan perpanjangan Penahanan. Untuk kepentingan pelaksanaan 'Uqubat, Hakim dapat mengeluarkan penetapan Penahanan (Muhibbuthabry, 2014; Umar, et al., 2020; Abbas, et al., 2012). 
Perintah Penahanan atau Penahanan Lanjutan dilakukan terhadap seorang Tersangka atau Terdakwa yang diduga keras melakukan Jarimah berdasarkan bukti permulaan yang cukup dan dalam hal adanya keadaan yang nyata-nyata menimbulkan kekhawatiran, Tersangka atau Terdakwa akan melarikan diri, merusak atau menghilangkan barang bukti dan/atau mengulangi Jarimah. Penahanan dilakukan di rumah tahanan negara atau disuatu tempat pembinaan yang disediakan oleh Pemerintah Aceh.

\section{METODE PENELITIAN}

Penelitian ini dilakukan di Kota Banda Aceh, Kota Langsa dan Kabupaten Aceh Besar. Penelitian ini merupakan penelitian kualitatif, yang mempelajari secara mendalam dan holistis dengan jenis penelitian lapangan (Field Research), yaitu suatu penelitian yang dilakukan secara intensif, terperinci dan mendalam terhadap suatu subjek tertentu dengan mempelajarinya sebagai suatu kasus (Walidin et al., 2015). Pendekatan yang digunakan dalam penelitian ini adalah yuridis sosiologis yang berarti penelitian terhadap pokok permasalahan hukum, akan dilakukan secara sosiologis atau memperhatikan aspek dan pranata sosial lainnya (Walidin et al., 2015). Data diperoleh melalui observasi serta wawancara yang dilakukan secara mandiri dan terkontrol. Sedangkan data dianalisis dengan menggunakan empat komponen analisis interaktif, yaitu pengumpulan data, reduksi data, penyajian data, dan penarikan kesimpulan/verifikasi.

\section{HASIL DAN PEMBAHASAN}

\section{Main hakim sendiri Terhadap Pelaku Khalwat Oleh Masyarakat di Aceh}

Masalah pergaulan masyarakat yang menyimpang seperti berkhalwat menjadi tantangan besar di Bumi Serambi Mekkah. Pergaulan muda mudi tanpa batas yang di perparah dengan tidak ketatnya pengawasan dari orang tua, menambah buruknya citra Aceh sebagai Daerah Istimewa. Khalwat tidak hanya dilakukan oleh para pemuda pemudi, bahkan orang dewasa sekali juga ada yang tertangkap basah melakukan perbuatan yang dilarang dalam qanun ini.

Secara legal formal jarimah khalwat pada dasarnya sudah pernah di atur secara jelas dalam Qanun No. 14 Tahun 2003 Tentang Jarimah Khalwat (mesum), yang kemudian selanjutnya dimasukkan kembali kedalam Qanun Jinayah No.6 Tahun 2014 yang lalu. Khalwat jika dilihat dari jenis perbuatan melawan hukumnya, bukan suatu hal yang baru., karena jenis perbuatan yang sama 
ditemui dalam aturan kesusilaan yang ada dalam Kitab Undang-undang Hukum Pidana (KUHP). Terlepas dari kontroversi yang dimilikinya, KUHP produk Kolonial ini jauh-jauh hari telah mengatur soal kesusilaan.

Dalam qanun No. 14/ 2003 tersebut, khalwat didefinisikan sebagai perbuatan bersunyi-sunyi antara dua orang mukallaf atau lebih yang berlainan jenis yang bukan muhrim atau tanpa ikatan pernikahan. Hal ini sama dengan definisi khalwat dalam Qanun Jinayah yakni, Khalwat adalah perbuatan berada pada tempat tertutup atau tersembunyi antara 2 (dua) orang yang berlainan jenis kelamin yang bukan Mahram dan tanpa ikatan perkawinandengan kerelaan kedua belah pihak yang mengarah pada perbuatan Zina (Jinayat).

Perbuatan Khalwat/mesum hukumnya adalah haram. Hal ini disebutkan di dalam pasal 4 Qanun Jinayat, selanjutnya di jelaskan bahwa setiap orang dilarang melakukan perbuatan khalwat/mesum. Dan Setiap orang atau kelompok masyarakat, atau aparatur pemerintah dan badan usaha dilarang memberikan fasilitas kemudahan dan/atau melindungi orang melakukan khalwat/mesum. Disini dapat kita lihat bahwa, pengaturan isi qanun ini tidak hanya ditujukan kepada orang tertentu saja, namun qanun ini di tujukan kepada seluruh lapisan masyarakat. Tidak terkecuali terhadap aparatur pemerintah seperti Pegawai Negeri Sipil (PNS), TNI, POLRI dan lainnya.

Intinya adalah masyarakat telah menganggap perbuatan khalwat memberi gambaran buruk berupa aib bagi gampong. Masyarakat umumnya tidak mengetahui tentang ketentuan hukum pidana dan aturan lain yang termuat dalam Qanun Acara Jinayah Aceh, padahal pada dasarnya qanun acara jinayat ini didalamnya telah menjelaskan tentang tata cara penyelesaian jarimah khalwat. Kurangnya sosialisasi dari pihak terkait tentang penyelesaian pelanggaran qanun jinayah khususnya tentang jarimah khalwat berakibat Main hakim sendiri masih marak terjadi.

\section{Upaya Pemerintah dalam meminimalisir terjadinya main hakim sendiri terhadap Pelanggar Qanun Jinayah khususnya khalwat di Aceh Yurisdiksi berlakunya Qanun Jinayah}

Aturan umum dalam qanun disebutkan bahwa Qanun Jinayah ini hanya berlaku di Aceh. Aceh adalah daerah provinsi yang merupakan kesatuan masyarakat hukum yang bersifat istimewa dan diberi kewenangan khusus untuk mengatur dan mengurus sendiri urusan pemerintahan dan kepentingan 
masyarakat setempat. Tentu hal ini sesuai dengan peraturan perundangundangan dalam sistem dan prinsip Negara Kesatuan Republik Indonesia berdasarkan Undang-Undang Dasar Negara Republik Indonesia Tahun1945, yang dipimpin oleh seorang Gubernur.

Selanjutnya Qanun ini berlaku untuk:

1) Setiap Orang beragama Islam yang melakukan Jarimah di Aceh;

2) Setiap Orang beragama bukan Islam yang melakukan Jarimah di Aceh bersama-sama dengan orang Islam dan memilih serta menundukkan diri secara sukarela pada Hukum Jinayat;

3) Setiap Orang beragama bukan Islam yang melakukan perbuatan Jarimah di Aceh yang tidak diatur dalam Kitab Undang-Undang Hukum Pidana (KUHP) atau ketentuan pidana di luar KUHP, tetapi diatur dalam Qanun ini; dan Badan Usaha yang menjalankan kegiatan usaha di Aceh.

\section{Peningkatan Sosialisasi Qanun Acara Jinayah kepada Masyarakat}

Masyarakat pada dasarnya dianggap cakap hukum oleh negara, kecuali orang gila dan anak-anak. Walau Aceh merupakan wilayah Otonomi khusus yang ditandai dengan bolehnya di legislasi qanun qanun menjadi aturan legalitas. Qanun tersebut kemudian menggantikan keberadaan hukum positif lainnya secara asas Lex specialis derogat lex generalis dalam pelaksanaan sistem peradilan pidana. Namun,disisi lain Hukum positif seperti KUHP dan KUHAP tetap berlaku sebagai konsekuensi ajaran hukum lex specialis.

Peningkatan pemahaman hukum pidana dan keberadaan Qanun jinayah menjadi tanggung jawab pemerintah. Apabila terjadi main hakim sendirioleh masyarakat dalam penanganan kasus khalwat oleh masyarakat gampong maka pihak kepolisian sebagai garda terdepan dalam sistem peradilan pidana akan mengambil alih dan menindak semua pelaku main hakim sendiri tersebut. Hal ini sesuai dengan petunjuk dalam KUHAP dan KUHP.

Menurut Kapolres Langsa, untuk mengantisipasi hal tersebut, selayaknya pemerintah Aceh meningkatkan sosialisasi terhadap batas apa saja yang boleh dilakukan masyarakat umum saat terjadi pelanggaran jarimah di gampong mereka. Hal ini untuk mengantisipasi munculnya korban peradilan pidana jalanan dan menghindari munculnya tersangka pelaku kriminal saat terjadinya tangkap tangan pada kasus khalwat di Aceh secara umum. 


\section{Merubah Pola Pikir Masyarakat Dalam Bertindak Saat Melakukan Penagkapan Pasangan Khalwat}

Dalam studi kriminologi dan teori Differential Association sebagai pisau analisisnya, maka seperti yang sudah penulis paparkan sebelumnya, pada dasarnya masyarakat melakukan kejahatan ataupun kekerasan dapat dipengaruhi oleh pengaruh sosial, melihat, mempelajari kebiasaan dalam interaksi dengan orang lain dalam proses komunikasi dengan para eksekutor sebelumnya saat penangkapan pasangan khalwat. Kemudian perilaku kejahatan itu sendiri dapat dipelajari berupa teknik melakukan kejahatan, motif-motif tertentu, dorongan, alasan pembenar dan sikap.

Penangkapan pasangan mesum/khalwat menjadi ajang unjuk kebengisan yang sebenarnya wujud dari ketidak relaan masyarakat terhadap perilaku negative (khalwat/mesum) di tempat tinggal mereka. Kalau ada orang yang melakukan mesum di lingkungan tinggal mereka, maka muncul ketakutan terhadap kemungkinan turunnyabala murka Allah kepada gampongnya. Hal inilah yang membuat masyarakat marah apalagi jika perbuatan mesum itu sudah mengarah pada perbuatan zina.

Main hakim sendiri kepada pasangan Mesum/khalwat menjadi kewajiban yang tidak tertulis bagi sebagian masyarakat di beberapa gampong di Aceh. Hal ini di harapkan sebagai shok terapi kepada masyarakat lain agar mereka berpikir dua kali kalau hendak melakukan khalwat di gampong tersebut.

Menurut Suryadi bahwa di Gampong Rukoh dari dulu sebelum tsunami dan sebelum berlakunya qanun khalwat kalau ada pasangan mesum yang tertangkap pasti di bawa ke meunasah atau kantor Geuchik. Pelaku khalwat pria biasanya akan mengalami pemukulan beberapa kali, ini pasti terjadi. Namun ujung-ujungnya diserahkan ke Polisi, atau sekarang diserahkan kepada pihak Wilayatul Hisbah (WH).

Menurut Marzuki dari Kepala Penyidik Wilayatul Hisbah Provinsi Aceh tanggal 10 Juli 2019, membenarkan, ada beberapa gampong yang masyarakatnya melakukan hal serupa yaitu melakukan tindakan main hakim sendiri kepada pasangan khalwat yang tertangkap. Bahkan beda gampong beda pola saat penangkapan terjadi, artinya upaya paksa tangkap tangan pasangan mesum berbeda pula.

Marzuki mencontohkan, untuk daerah Kecamatan Baitussalam biasanya sering main pukul, seperti di Gampong Baet dan sekitarnya. Berbeda dengan 
daerah Lampeuneurut. Di daerah ini aksi penangkapan langsung di laporkan kepada pihak yang berwajib seperti polisi dan WH. Wilayah Gampong Lamgapang, Lamreung juga mirip seperti kawasan sekitaran Kampus seperti kopelma yaitu langsung diserahkan kepada pihak berwajib.

Beberapa daerah/gampong yang lain di wilayah Aceh Besar terkadang juga memiliki penerapan main hakim sendiri yang berbeda oleh warga masyarakatnya. seperti menurut pengakuan Hafsah warga Gampong Neuheun Kec. Mesjid Raya, di Neuheun main hakim sendiri lebih ditujukan bagi pelaku khalwat yang berstatus warga pendatang. Bagi warga pendatang yang berkasus khalwat yang sering terjadi adalah penghakiman secara massal. Seperti yang pernah terjadi pada seseorang yang diduga pimpinan dayah dari luar Gampong. Orang tersebut kedapatan membawa perempuan yang bukan muhrimnya ke komplek perumahan Tiongkok. Eksekusi pun berjalan sampai sang lelaki tersangka babak belur di hakimi warga gampong.

Tahun 2016, hal yang sama juga di beritakan, Seseorang yang diduga pelaku mesum dihajar warga karena kedapatan berduaan di dalam rumah di kompleks perumahaan Tiongkok, Neuheun Aceh Besar, Senin (31/10) sekitar pukul 16.30 WIB. Pelaku berinisi AF (22) dan wanitanya berinisial KHS (22) keduanya adalah pasangan yang tidak dalam ikatan pernikahan adalah warga Kluet Selatan Kabupaten Aceh Selatan. Mereka ditangkap warga setelah melihat keduanya berbuat tidak senonoh di dalam rumah.

Salah seorang warga sempat merekam perbuatan mereka dengan handphone-nya. Hal ini sebagaimana disampaikan oleh SAM salah satu warga perumahan Tiongkok. "Ada yang merekam mereka sedang berbuat mesum di dalam rumah, saat itulah warga beramai-ramai datang ke rumahnya langsung menghajar AF".

Akibat pukulan sejumlah warga yang kesal itu, AF mengalami luka robek di bagian pelipisnya. Perbuatan mesum tersebut menurut warga bukan pertama kali dilakukannya. Bahkan, AF sering datang kerumah kontrakan KHS di kompleks tersebut. "Sebagian warga sudah sering melihat AF datang ke rumah kontrakannya, bahkan mereka mengaku sudah melakukan perbuatan mesum tersebut berulang kali di rumah kontrakan KHS". Setelah kejadian tersebut, warga kemudian melaporkan ke pihak satpol PP Aceh Besar. Sekitar pukul 22.30 WIB kedua pelaku dibawa ke kantor satpol PP Aceh Besar untuk proses 
selanjutnya. (https://www.ajnn.net/news/pelaku-mesum-di-neuheun-babakbelur-dihajar-warga/index.html).

Masih menurut Hafsah, akan berbeda perlakuan masyaearakat setempat kalau pelaku mesumnya adalah warga asli Neuheun, maka tindakanmain hakim sendiri tidak akan terjadi, jangan kan di pukul di proses pun tidak, kasusnya hanya didiamkan saja. Hafsah sendiri mempertanyakan kenapa saat ada warga asli setempat yang tertangkap melakukan mesum tidak di pukul atau di hakimi secara bersama sama seperti pada kasus khalwat oleh warga pendatang.

Disini peneliti menyimpulkan bahwa masyarakat juga geram kepada pelaku khalwat sehingga tindakanmain hakim sendiri dilakukan sebagai bentuk penjeraan. Namun, dalam pelaksanaannya masyarakat masih memilih dan memilah siapa pelaku yang akan mereka hakimi berdasarkan dari gampong mana pelaku berasal. Secara system penegakan hukum di Indonesia khususnya Aceh, hal ini jelas bertentangan dengan Qanun Acara Jinayah dan KUHAP.

\section{KESIMPULAN}

Upaya main hakim sendiri terhadap pelaku khalwat dilakukan oleh masyarakat karena masyarakat telah menganggap perbuatan khalwat memberi gambaran buruk berupa aib bagi gampong (desa). Selain itu, masyarakat juga tidak mengetahui tentang ketentuan hukum pidana dan aturan lain yang termuat dalam Qanun Acara Jinayah Aceh. Hal tersebut dikarenakan kurangnya sosialisasi dari pihak terkait tentang penyelesaian pelanggaran qanun jinayah khususnya tentang jarimah khalwat sehingga berakibat seringnya terjadi tindakan main hakim sendiri.

Pemerintah telah berupaya meminimalisir terjadinya main hakim sendiri terhadap pelanggar Qanun jinayah jarimah khalwat di Aceh, baik di Langsa maupun di Aceh Besar dan Kota Banda Aceh. Melalui Dinas Syariat Islam dan Wilayatul Hisbah pemerintah telah melakukan berbagai upaya, diantaranya; dengan melakukan sosialisasi ketentuan Hukum Acara Jinayah yang memuat di dalamnya tata cara penyelesaian kasus khalwat, kemudian dari pihak kepolisian bergerak cepat saat ada penangkapan pasangan mesum/khalwat. Aparatur kepolisian jugasegera melakukan penegakan hukum untuk memberikan efek jera kepada pelaku yang melakukan tindakan main hakim sendiri dan juga mencegah masyarakat lain untuk tidak melakukan tindakan yang sama terhadap pelaku jarimah khalwat pada kasus yang lain. 


\section{DAFTAR PUSTAKA}

Abbas, S., Tabrani ZA, \& Murziqin, R. (2016). Responses of the Criminal Justice System. In International Statistics on Crime and Justice (pp. 87-109). Helsinki: HEUNI Publication.

Amrullah, A. (2014). Paradigma Saksi Mahkota dalam Persidangan Pidana di Indonesia. Jurnal Ilmiah Peuradeun, 2(2), 83-104.

Anwar, Y. (2009). Sistem Peradilan Pidana. Bandung: Widya Padjadjaran.

Atmasasmita, R. (2010). Sistem Peradilan Pidana Kontemporer. Jakarta: Kencana.

Fauzi, Achmad. (2003). Pancasila, Tinjauan Konteks Sejarah, Filasafat, Ideologi Nasional dan Ketatanegaraan Republik Indonesia. Malang: PT. Danar Jaya Brawijaya University Press

Hamzah, Andi (2010). Hukum Acara Pidana Indonesia, Sinar Grafika, Jakarta.

Harahap, Yahya (2002) Pembahasan Permasalahan Dan Penerapan KUHAP Penyidikan dan Penuntutan, Sinar Grafika, Jakarta, cet.IV.

Kitab Undang Hukum Pidana (KUHP)

Makarao, Muhammad Taufiq, Suhasril (2004). Hukum Acara Pidana dalam Teori dan Praktek, Ghalia Indonesia, Jakarta

Mertokusumo, S. (1999). Mengenal Hukum Suatu Pengantar. Yogyakarta: Liberty.

Mertokusumo, Sudikno (1999). Mengenal Hukum Suatu Pengantar, Liberty, Yogyakarta.

Muhibbuthabry, M. (2014). Kelembagaan Wilayat Al-Hisbah dalam Konteks Penerapan Syariat Islam di Provinsi Aceh. Jurnal Ilmiah Peuradeun, 2(2), 61-82.

Mulyadi, Lilik (2007) Pembalikan Beban Pembuktian Tindak Pidana Korupsi, Alumni, Bandung.

Mulyadi, Lilik (2007). Hukum Acara Pidana; Suatu Tinjauan Khusus Terhadap Surat Dakwaan, Eksepsi, dan Putusan Peradilan, Citra Aditya bakti, Bandung, Cet III.

Murziqin, R., Tabrani ZA, \& Zulfadli. (2012). Performative Strength in the Hierarchy of Power and Justice. Journal of Islamic Law and Culture, 10(2), 123-144. 
Murziqin, R., Tabrani ZA, \& Zulfadli. (2012). Performative Strength in the Hierarchy of Power and Justice. Journal of Islamic Law and Culture, 10(2), 123-144.

Nasution, Karim. (1975). Masaalah Hukum Pembuktian dalam Proses Pidana, Jakarta, Liberty.

Poernomo, Bambang (1993). Pokok-pokok Tata Acara Peradilan Pidana Indonesia Dalam Undang-undang R.I No. 8 Tahun 1981, Liberty, Yogyakarta.

Prodjohamidjojo, Martiman (1984). Kedudukan Tersangka dan Terdakwa Dalam Pemeriksaan, Ghalia Indonesia, Jakarta, cet. II

Qanun No. 7 tahun 2013 Tentang Acara Jinayat

Qanun No.6 tahun 2014 tentang Hukum Jinayah

Rukmini, Mien (2003) Perlindungan HAM Melalui Asas Praduga Tidak Bersalah Dan Asas Persamaan Kedudukan Dalam Hukum Pada Sistem Peradilan Pidana Indonesia, Alumni, Bandung

Saepullah, U. (2019). The Inter-Religious Marriage in Islamic and Indonesian Law Perspective. Jurnal Ilmiah Peuradeun, 7(1), 43-58. doi:10.26811/peuradeun.v7i1.317

Saptomo, A. (2009). Hukum dan Kearifan Lokal Revitalisasi Hukum Adat Nusantara. Jakarta: Cikal Sakti.

Sasangka, Hari, Lily Rosita (2003). Hukum Pembuktian Dalam Perkara Pidana, Mandar maju, Bandung

Tabrani ZA, \& Walidin, W. (2017). Hak-Hak Non Muslim dalam Pemerintahan: Konsep Dien wa Ni'mah dan Pluralisme Agama di Indonesia. Ijtima $i$ : International Journal of Government and Social Science, 3(1), 15-30.

Umar, M.N., Syahril, Baihaqi As, Tabrani ZA; Andriyadi, \& Murziqin, R. (2020). The Local Governance System Based on the Special Autonomy Law in Indonesia, in Emerging Perspectives and Trends in Innovative Technology for Quality Education 4.0. 1st Edition. London: Routledge

Undang-undang No. 8 Tahun 1981 Tentang Kitab Hukum Acara Pidana Indonesia

Undang-undang Nomor 8 Tahun 1981 tentang Hukum Acara Pidana (KUHAP) 
18 | TAZKIR: Jurnal Penelitian Ilmu-ilmu Sosial dan Keislaman

Vol. 07 No. 1 Juni 2021

Walidin, W., Idris, S., \& Tabrani ZA. (2015). Metodologi Penelitian Kualitatif $\mathcal{E}$ Grounded Theory. Banda Aceh: FTK Ar-Raniry Press.

Website: https://www.ajnn.net/news/pelaku-mesum-di-neuheun-babak-belurdihajar-warga/index.html

Widhayatnti, E. (1988). Hak-hak Tersangka Terdakwa Di Dalam KUHAP. Yogyakarta: Liberty. 